\title{
Survival, development and reproduction of Phenacoccus solenopsis (Hemiptera: Pseudococcidae) on kaolin-treated cotton
}

\author{
V. S. Guedes ${ }^{a}$ (D), C. A. D. Silva ${ }^{a, b *}$ (D) and J. C. Zanuncio \\ aPrograma de Pós-graduação em Ciências Agrárias, Universidade Estadual da Paraíba - UEPB, Rua Domitila Cabral de \\ Castro, Universitário, Rua Osvaldo Cruz, 1143, Centenário, CEP 58429-570, \\ Campina Grande, PB, Brasil

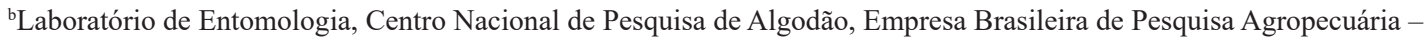 \\ EMBRAPA, CEP 58107-720, Campina Grande, PB, Brasil \\ 'Departamento de Entomologia/BIOAGRO, Universidade Federal de Viçosa - UFV, Avenida Peter Henry Rolfs, s/n, \\ Campus Universitário, CEP 36570-900, Viçosa, MG, Brasil \\ *e-mail: carlos.domingues-silva@embrapa.br
}

Received: November 6, 2018 - Accepted: August 12, 2019 - Distributed: November 30, 2020

\begin{abstract}
The mealybug, Phenacoccus solenopsis Tinsley (Hemiptera: Pseudococcidae) is a cotton pest widespread in several cotton growing regions of Brazil, particularly in the semi-arid region of southwestern Bahia. The impact of kaolin on survival, development and reproduction of $P$. solenopsis was evaluated in the laboratory. The experiment was developed in a completely randomized design with two treatments: immature or newly emerged adults of $P$. solenopsis sprayed with kaolin and fed with cotton leaf discs treated with kaolin suspension (with kaolin) (T1) and immature or newly emerged adults of $P$. solenopsis sprayed with distilled water and fed with cotton leaf discs treated with distilled water (without kaolin) (T2). The kaolin suspension shortens the life cycle, increases the reproductive potential and population growth of the cotton mealybug, $P$. solenopsis and, therefore, it should be used with caution on cotton plants in regions with a history of occurrence of this pest.
\end{abstract}

Keywords: biological traits, Gossypium hirsutum, mealybug, particle film, stimulatory effects.

\section{Sobrevivência, desenvolvimento e reprodução de Phenacoccus solenopsis (Hemiptera: Pseudococcidae) em algodão tratado com caulim}

\begin{abstract}
Resumo
A cochonilha Phenacoccus solenopsis Tinsley (Hemiptera: Pseudococcidae) é uma praga de algodão, amplamente, difundida em várias regiões produtoras do Brasil, particularmente, na região semiárida do sudoeste da Bahia. O impacto do caulim na sobrevivência, desenvolvimento e reprodução de P. solenopsis foi avaliado em laboratório. O delineamento experimental foi inteiramente casualizado com dois tratamentos: imaturos ou adultos recém-emergidos de $P$. solenopsis alimentados com discos foliares de algodão tratados com caulim (com caulim) e pulverizadas com este produto (T1) e imaturos ou adultos recém-emergidos de $P$. solenopsis alimentados com discos foliares de algodão tratados com água destilada (sem caulim) e pulverização dos insetos com água destilada (T2). A suspensão do caulim encurtou o ciclo de vida, aumentou o potencial reprodutivo e o crescimento populacional da cochonilha-do-algodoeiro, P. solenopsis e, portanto, deve ser utilizado com cautela em plantas de algodão em regiões com histórico de ocorrência desta praga.
\end{abstract}

Palavras-chave: características biológicas, Gossypium hirsutum, cochonilha, filme de partículas, efeito estimulante.

\section{Introduction}

Cotton plants host a high boll, leaf, root, square and stem pest complex (Allen et al., 2018). The mealybug, Phenacoccus solenopsis Tinsley (Hemiptera: Pseudococcidae) is a major cotton pest in several countries (Nagrare et al., 2016). This insect sucks cotton sap, injects toxins and secretes "honeydew" stimulating the development of black sooty moulds which adversely affect photosynthesis (Joshi et al., 2010).

In Brazil, P. solenopsis severely infests cotton plants in Southwest and mid São Francisco, Bahia State (Silva,
2012). Heavy infestation of the cotton mealybug may result from the absence of natural enemies of this invasive pest (Noureen et al., 2016). Parasitoids (Aslam et al., 2017; Karmakar and Shera, 2017; Joodaki et al., 2018) and predators (Arif et al., 2012; Zazycki et al., 2015; Aslam et al., 2017; Lima et al., 2018) can control this mealybug. However, chemical control, with highly toxic insecticides to natural enemies, is the main method to reduce populations of this mealybug (Huang et al., 2012; Karmakar and Shera, 2017). 
New insecticide formulations have been developed with effective physicochemical properties against $P$. solenopsis including natural products with potential to substitute conventional chemical insecticides (Silva and Ramalho, 2013; Silva and Silva, 2015). These products need to be biodegradable and selective, characteristics largely found in plant extracts or in minerals.

Kaolin, a white clayey mineral that dissolves to form a white syrup in water, has been successfully used to protect cotton plants against pests, including the boll weevil, Anthonomus grandis (Boheman, 1843) (Coleoptera: Curculionidae) (Silva and Ramalho, 2013); cotton leafworm, Alabama argillacea (Hübner, 1818) (Lepidoptera: Noctuidae) (Gonçalves et al., 2015); cotton bollworm, Helicoverpa armigera (Hübner, 1809) (Lepidoptera: Noctuidae) (Alavo et al., 2011); beet armyworm, Spodoptera exigua (Hübner, 1808) (Lepidoptera: Noctuidae) (Showler, 2003); pink bollworm, Pectinophora gossypiella (Saunders, 1844) (Lepidoptera: Gelechiidae) (Sisterson et al., 2003) and aphid, Aphis gossypii (Glover, 1877) (Homoptera: Aphididae) (Alavo et al., 2011), although adverse effects of its application were reported (Showler and Armstrong, 2007).

The main basic action of kaolin particle film against pest insects is due to its interference during the host plant location and acceptance process by the insect. Indeed, the white particle films of kaolin on plants alters the visual and tactile recognization and smell inducing repellence from treated foliage and a consequent feeding and oviposition by insects (Glenn and Puterka, 2005). The kaolin may affect the moisture of the cotton leaf surface and, consequently, the feeding and oviposition behavior of $P$. solenopsis on its leaves. However, kaolin has specific action against each pest (Silva and Ramalho, 2013) and, therefore, understanding its impact on sucking insects can minimize failures when used against these organisms.

The objective of the present study was to assess kaolin effects on the survival, development and reproduction of P. solenopsis on cotton plants.

\section{Material and Methods}

\subsection{Site and insect}

Experiments were conducted at Embrapa Algodão Entomology Laboratory, Campina Grande, Paraíba State, Brazil in climatic chambers with a temperature of $25 \pm 1{ }^{\circ} \mathrm{C}$, relative humidity of $60 \pm 10 \%$ and photophase of 12 hours.

The $P$. solenopsis specimens were collected from an experimental cotton crop of the Embrapa Algodão.

\subsection{Biology and life table}

One hundred adult $P$. solenopsis were transferred from the stock-rearing unit to leaves of the cotton cultivar BRS 286 for oviposition and obtainment of first instar nymphs of this pest. The nymphs were collected forty-eight hours after transferring the females of this mealybug to the cotton leaves.

The experiment was developed in a completely randomized design with two treatments: immature or newly emerged adults of $P$. solenopsis sprayed with kaolin and fed with cotton leaf discs treated with kaolin suspension (with kaolin) (T1) and immature or newly emerged adults of $P$. solenopsis sprayed with distilled water and fed with cotton leaf discs treated with distilled water (without kaolin) (T2). Fifty replications were used. A manual pre-compressed sprayer (Guarany Indústria e Comércio Ltda, Itu, SP, Brazil) with a 1.2 L volume capacity and empty cone nozzle was used to spray the newly emerged immature and adult $P$. solenopsis. The kaolin particle film was applied at a concentration of $60 \mathrm{~g}$ of kaolin/L of water based on previous studies with sap-sucking cotton pests (Showler and Armstrong, 2007).

Fifty-five $P$. solenopsis newly emerged first instar nymphs were individually maintained per rearing unit of PVC tubes $(2.5 \mathrm{~cm} \times 2.0 \mathrm{~cm})$ sealed at the base. A moistened filter paper was inserted inside the tubes and a cotton leaf disc (2.4 $\mathrm{cm}$ diameter) collected from the cotton leaf ventral side. The rearing units were covered with a transparent plastic film and maintained in climatic chambers until the conclusion of observations.

Biological observations were performed daily at 8:00 A.M. and 04:00 P.M. with stereoscopic microscope. The development, duration and survival of each instar and of the nymph stage, besides the pre-oviposition, oviposition and post-oviposition periods, longevity, fecundity and number of eggs/day and of eggs/female/day of $P$. solenopsis were evaluated. The adults of this insect were sexed based on sexual dimorphism and separated into couples with the newly emerged males and females individualized in pairs in new arenas. The fertility and sex ratio of the progeny on the cotton leaf discs, with and without kaolin, were determined. The number of $P$. solenopsis eggs in these arenas was quantified daily at 04:00 P.M.

\subsection{Data analysis and statistics}

Development data of $P$. solenopsis males and females were submitted to homoscedasticity tests and to the analysis of variance (ANOVA) and the means compared by LSD.

The $P$. solenopsis reproductive data were organized for life table calculations (Silveira et al., 1976). The reproductive rate net values $(\mathrm{Ro}=\Sigma \mathrm{mx} .1 \mathrm{x}-\mathrm{mx}$ : total eggs/female number; 1x: alive individuals/total), gross reproductive, also expressed in units of number of females per female $\left(\mathrm{GRR}=\sum_{x=0}^{n} m x\right.$ generation time $(\mathrm{T}=\mathrm{mx} . \mathrm{lx} . \mathrm{x} / \mathrm{mx} . \mathrm{lx} \Sigma)$, intrinsic rate $\left(r_{m}=\log\right.$ Ro/T.0.4343), and finite $\left(\lambda=\operatorname{antilog} r_{m}\right)$ rate of increase were calculated. The confidence intervals of the means were estimated with these parameters determined using the SAS computer program (SAS Institute, 2008) applying the Jackknife resampling technique (Maia et al., 2000).

\section{Results}

The survival of immature $P$. solenopsis had no interactions with the treatment duration (Table 1) but differed between its stages. The survival of $P$. solenopsis second and third 
instars and of the pupa stage was highest and that of the first instar lowest in both treatments (Table 2).

The duration of the P. solenopsis immature stage showed no interaction with the treatments (Table 2), but it differed between treatments and immature stages. The duration of second and third instar and of the egg to adult period of females was longer with distilled water (without kaolin) and shorter with kaolin.

The duration of pre-oviposition and oviposition periods of $P$. solenopsis were, respectively, shorter and longer with kaolin, but that of the post-oviposition was similar between treatments (Table 3). The number of eggs per female and their fecundity were higher with kaolin, but that of eggs per day was similar between treatments.
Phenacoccus solenopsis longevity was similar between treatments $\left(\mathrm{F}_{1.33}=1.64, \mathrm{P}=0.21\right)$ and differed between sex of this insect $\left(\mathrm{F}_{1.33}=180.62 ; \mathrm{P}<0.01\right)$, with females always outliving the males.

The duration of one generation (DG) and the period for the $P$. solenopsis to double its population in numbers (DT) did not differ between treatments (Table 4). The positive $\mathrm{r}_{\mathrm{m}}$ and $\lambda$ values show that $P$. solenopsis populations tend to grow, exponentially, in both treatments. On the other hand, the gross (GRR) and net (Ro) reproductive rates and the intrinsic $\left(\mathrm{r}_{\mathrm{m}}\right)$ and finite $(\lambda)$ rate of increase differed with higher values with the kaolin suspension, indicating that the particle film increased this mealybug biotic potential.

Table 1. Summary of the effects of the treatments* and immature stages on the development and survival period** of the immature stages of Phenacoccus solenopsis (Hemiptera: Pseudococcidae) using the analysis of variance (ANOVA).

\begin{tabular}{clccc}
\hline Source & \multicolumn{1}{c}{ Model } & DF & F & P \\
\hline Development (days) & Treatment (T) & 1 & 15,33 & $<0,01$ \\
& Immature stage (IS) & 5 & 444,45 & $<0,01$ \\
& T $\times$ IS & 5 & 1,36 & $>0,05$ \\
Survival (\%) & Residue & 144 & - & - \\
& Treatment (T) & 1 & 0,03 & $>0,05$ \\
& Immature stage (IS) & 5 & 17,96 & $>0,01$ \\
& T $\times$ IS & 5 & 0,14 & $-0,05$ \\
\hline
\end{tabular}

*Treatments: spraying the immature and newly emerged adult $P$. solenopsis and immersing cotton leaf discs with kaolin suspension in $60 \mathrm{gL}^{-1}$ distilled water or with distilled water (control); $* *$ Survival: data transformed into square root of $\mathrm{x}+0.5$. DF $=$ degrees of freedom; $\mathrm{F}=$ Fisher test; $\mathrm{P}=$ probability.

Table 2. Survival (\%) and development (mean \pm standard error) of the immature stages and of the egg to adult of Phenacoccus solenopsis (Hemiptera: Pseudococcidae) on the cotton leaf disks treated with kaolin suspension and distilled water (control).

\begin{tabular}{lccccrc}
\hline \multirow{2}{*}{ Stages } & \multicolumn{7}{c}{ Treatments } \\
\cline { 2 - 7 } & Ind. & Sur. (\%) & With kaolin & Ind. & Sur. (\%) & Without kaolin \\
\hline $1^{\circ}$ instar & 50 & $40.0 \mathrm{a}^{*} \mathrm{~B}^{* *}$ & $6.50 \pm 0.19 \mathrm{aB}$ & 50 & $44.0 \mathrm{aB}$ & $6.75 \pm 0.28 \mathrm{aB}$ \\
$2^{\circ}$ instar & 18 & $90.0 \mathrm{aA}$ & $3.92 \pm 0.10 \mathrm{bC}$ & 22 & $100.0 \mathrm{aA}$ & $4.80 \pm 0.40 \mathrm{aC}$ \\
$3^{\circ}$ instar & 12 & $100.0 \mathrm{aA}$ & $5.25 \pm 0.11 \mathrm{bC}$ & 10 & $90.0 \mathrm{aA}$ & $6.17 \pm 0.14 \mathrm{aC}$ \\
Pupa & 06 & $100.0 \mathrm{aA}$ & $7.83 \pm 0.28 \mathrm{aA}$ & 10 & $90.0 \mathrm{aA}$ & $7.95 \pm 0.46 \mathrm{aA}$ \\
Egg-Adult female & 12 & $37.0 \mathrm{aA}$ & $15.75 \pm 0.28 \mathrm{bB}$ & 10 & $40.0 \mathrm{aA}$ & $17.50 \pm 0.42 \mathrm{aB}$ \\
Egg-Adult male & 06 & $35.0 \mathrm{aA}$ & $17.92 \pm 0.32 \mathrm{aA}$ & 10 & $40.0 \mathrm{aA}$ & $19.50 \pm 0.90 \mathrm{aA}$ \\
\hline
\end{tabular}

Means followed by the same lowercase letter per row* or upper** case per column do not differ by the F- LSD test $(\mathrm{P}<0.05)$. Ind. $=$ number of individuals per stages and treatment; Sur. $=$ Survival

Table 3. Reproductive characteristics (mean \pm standard error) of Phenacoccus solenopsis (Hemiptera: Pseudococcidae) on the cotton leaf disks treated with kaolin suspension and distilled water (control).

\begin{tabular}{lcc}
\hline \multicolumn{1}{c}{ Variables } & With kaolin & Control \\
\hline Pre-oviposition period (days) & $9.50 \pm 0.34 \mathrm{~b}^{*}$ & $10.83 \pm 0.28 \mathrm{a}$ \\
Oviposition period (days) & $22.67 \pm 2.11 \mathrm{a}$ & $15.17 \pm 1.38 \mathrm{~b}$ \\
Post-oviposition period (days) & $1.50 \pm 0.94 \mathrm{a}$ & $2.50 \pm 1.28 \mathrm{a}$ \\
Number of eggs per female & $24.61 \pm 4.66 \mathrm{a}$ & $18.81 \pm 3.05 \mathrm{~b}$ \\
Number of eggs per day & $29.32 \pm 5.24 \mathrm{a}$ & $22.19 \pm 4.74 \mathrm{a}$ \\
Fecundity & $642.00 \pm 71.53 \mathrm{a}$ & $374.84 \pm 117.21 \mathrm{~b}$ \\
Sex rate & 0.67 & 0.47 \\
\hline
\end{tabular}

*Means followed by the same lower case letter per line do not differ by the F- LSD test $(\mathrm{P}<0.05)$. 
Table 4. Parameters of the fertility life table of Phenacoccus solenopsis (Hemiptera: Pseudococcidae) on the cotton leaf disks treated with kaolin suspension and distilled water (control).

\begin{tabular}{lcc}
\hline \multicolumn{1}{c}{ Parameters } & With kaolin & Control \\
\hline Gross reproduction rate $(\mathrm{GRR})$ & $443.00 \mathrm{a} *$ & $194.78 \mathrm{~b}$ \\
Net reproductive rate $(R o)$ & $79.38 \mathrm{a}$ & $44.27 \mathrm{~b}$ \\
Duration of a generation $(D G)$ & $20.50 \mathrm{a}$ & $20.47 \mathrm{a}$ \\
Intrinsic rate of increase $\left(r_{m}\right)$ & $0.21 \mathrm{a}$ & $0.18 \mathrm{~b}$ \\
Finite rate of increase $(\lambda)$ & $1.24 \mathrm{a}$ & $1.20 \mathrm{~b}$ \\
Period for the population to double in numbers $(T D)$ & $3.24 \mathrm{a}$ & $3.67 \mathrm{a}$ \\
\hline
\end{tabular}

*Means followed by the same lower case letter per line do not differ by the F- LSD test $(\mathrm{P}<0.05)$.

\section{Discussion}

Kaolin did not affect $P$. solenopsis immature stage survival. However, the second and third instar and $P$. solenopsis egg to adult period for females on cotton leaf discs with kaolin was shorter than without this particle film. The higher nymph vulnerability of this instar to the kaolin suspensions and water is due to the thinner wax layer of their bodies compared to older individuals. Additionally, the removal of these nymphs from the female ovisac may decrease their survival. Wax on the coccids forms a physical or chemical barrier against parasitoids, predators and the external environment (Foldi, 1983; Zhang et al., 2012). The ovisac represents a physical barrier against predatory insects and its hydrophobic properties enable the mealybug females to keep their interior morphological structure dry (Zhang et al., 2012).

The shorter duration of the second and third instar and of the egg to adult period of $P$. solenopsis females with kaolin can be explained by the absorption of moisture from kaolin on the cotton leaf disk surface due to its hygroscopic properties, associated with an ambient temperature of $25^{\circ} \mathrm{C}$. Water shortage, like any other stress, has the potential to change the plant suitability for insect development, colonization, oviposition, and offspring survival (Blaney and Simmonds, 1988; Ramaswamy, 1988; Torres and Ruberson, 2006). These modifications in plant quality may favor or not insect pest damage (White, 1969; Mattson Junior and Haack, 1987; Bostanian and Racette, 2008; Markó et al., 2008; Showler and Armstrong, 2007), especially by sapsucking species (White, 1969; Miles et al., 1982; Oliveira et al., 2014). Likewise, the combination between high temperatures with low moisture content may shorten the insect development. This has been demonstrated for the Cephalcia arvensis (Panzer, 1805) (Hymenoptera: Pamphiliidae) larval development (Battisti, 1993). However, the longer duration of the egg to adult period of males compared to females seems to be common for this mealybug genus (Vennila et al., 2010; Prasad et al., 2012; Tok et al., 2016).

The longer oviposition period and the higher fecundity and number of eggs per $P$. solenopsis female with kaolin indicate a positive influence of this mineral particle film on the reproduction of this mealybug. This is probably due to the moisture reduction in the cotton leaf disk surfaces from kaolin water absorption. Variability in environmental moisture can also affect insect egg morphology, embryo physiology and oviposition. Low moisture content may stimulate egg cooling by evaporation, thereby protecting them from short thermal shocks and maintaining their viability (Potter, 2010). Host quality, food, light intensity and relative humidity (Vennila et al., 2010; Asifa et al., 2012; Fand et al., 2014) in addition to the kaolin particle film may affect insect fecundity. The longer longevity of females compared to males is due to the fact that males of this mealybug family present sexual dimorphism and shorter life span because they do not ingest food due to their nonfunctional and fragile mouthparts (Miller, 1991; Williams, 1991). Female longevity was $38.50 \pm 2.23$ days compared to the $3.50 \pm 0.33$ days for males, similar to the 35.6 days and 3.2 days for virgin female and mated male P. solenopsis with cotton leaves, respectively (Prasad et al., 2012).

The intrinsic rate of population increase $\left(r_{m}\right)$ links Ro and DG and demonstrates the biotic potential of the species (Price, 1997). The shorter time required for P. solenopsis to double its population (TD) as well as its higher crude (TBR) and net (Ro) reproductive rate with and without kaolin, demonstrates the favorable conditions from both treatments for this mealybug to increase its population.

The population growth of $P$. solenopsis sprayed with kaolin suspension, fed on cotton leaf discs treated with kaolin suspension, was higher. Kaolin apparently reduces the cotton foliar surface moisture and consequently, the duration of the life cycle while increasing mealybug reproduction. Kaolin also increased the population density of Aphis gossypii (Glover, 1877) (Homoptera: Aphididae) on cotton (Showler and Armstrong, 2007), and Archips argyrospila (Walker, 1863) (Lepidoptera: Tortricidae), Cydia pomonella (Linnaeus, 1758) (Lepidoptera: Tortricidae), Dysaphis plantaginea (Passerini, 1860) (Homoptera: Aphididae), Lyonetia clerkella (Linnaeus, 1758) (Lepidoptera: Lyonetiidae), Phyllonorycter blancardella (Fabricius, 1781) (Lepidoptera: Gracillariidae), Phyllonorycter elmaella (Doganlar \& Mutuura, 1980) (Lepidoptera: Gracillariidae), Phytomyza heringiana (Hendel, 1922) (Diptera: Agromyzidae), and Quadraspidiotus perniciosus (Comstock, 1881) (Homoptera, Diaspididae) on apple orchards (Markó et al., 2008; Bostanian and Racette, 2008). This demonstrates the need to evaluate the kaolin effects with different environmental conditions and cotton cultivars. Kaolin particles should be used with caution 
on cotton plants in regions with a history of $P$. solenopsis occurrence, particularly those in the semi-arid regions of northeastern Brazil.

\section{Conclusion}

The kaolin suspension shortens the life cycle, increases the reproductive potential and population growth of the cotton mealybug, $P$. solenopsis and, therefore, it should be used with caution on cotton plants in regions with a history of occurrence of this pest.

\section{Acknowledgements}

To "Conselho Nacional de Desenvolvimento Científico e Tecnológico (CNPq)" and "Coordenação de Aperfeiçoamento de Pessoal de Nível Superior (CAPES)”, for financial support. Dr. Phillip John Villani (University of Melbourne, Australia) revised and corrected the English language used in this manuscript.

\section{References}

ALAVO, T.B., ABAGLI, A.Z., TÉGBÉSSOU, K.J.C. and DUNPHY, G.B., 2011. Kaolin potential for the integrated management of Aphis gossypii Glov. (Homoptera: Aphididae) on cotton. Archiv für Phytopathologie und Pflanzenschutz, vol. 44, no. 8, pp. 764-770. http://dx.doi.org/10.1080/03235408.2010.507959.

ALLEN, K.C., LUTTRELL, R.G., SAPPINGTON, T.W., HESLER, L.S. and PAPIERNIK, S.K., 2018. Frequency and abundance of selected early-season insect pests of cotton. Journal of Integrated Pest Management, vol. 9, no. 1, pp. 20. http://dx.doi. org/10.1093/jipm/pmy010.

ARIF, M.I., RAFIQ, M., WAZIR, S., MEHMOOD, N. and GHAFFAR, A., 2012. Studies on cotton mealybug, Phenacoccus solenopsis (Pseudococcidae: Homoptera), and its natural enemies in Punjab, Pakistan. International Journal of Agriculture and Biology, vol. 14, no. 4, pp. 557-562.

ASIFA, H., AZIZ, M.A. and AHEER, G.M., 2012. Impact of ecological conditions on biology of cotton mealybug, Phenacoccus solenopsis (Hemiptera: Pseudococcidae) in laboratory. Pakistan Journal of Zoology, vol. 44, no. 5, pp. 685-690.

ASLAM, M.N., HAQ, E. and ASLAM, M., 2017. Rearing and release technology of two natural enemies (Cryptolaemus montrouzieri and Aenasius bambawalei) for the management of cotton mealybug. Pakistan Entomologist, vol. 39, no. 2, pp. 19-25.

BATTISTI, A., 1993. Bionomics of the spruce web-spinning sawfly Cephalcia arvensis Panzer (Hym., Pamphiliidae) in Northeastern Italy. Journal of Applied Entomology, vol. 115, no. 1-5, pp. 52-61. http://dx.doi.org/10.1111/j.1439-0418.1993.tb00363.x.

BLANEY, W.M. and SIMMONDS, M.S.J., 1988. Food selection in adult and larvae of three species of Lepidoptera: a behavioral and electrophysiological study. Entomologia Experimentalis et Applicata, vol. 49, no. 1, pp. 111-121. http:// dx.doi.org/10.1111/j.1570-7458.1988.tb02482.x.

BOSTANiAn, N.J. and RACETTE, G., 2008. Particles films for managing of arthropod pests of apple. Journal of Economic Entomology, vol. 101, no. 1, pp. 145-150. http://dx.doi.org/10.1093/ jee/101.1.145. PMid:18330129.
FAND, B.B., TONNANG, H.E.Z., KUMAR, M., KAMBLE, A.L. and BAL, S.K., 2014. A temperature-based phenology model for predicting development, survival and population growth potential to mealybug Phenacoccus solenopsis (Hemiptera: pseudococcidae). Crop Protection, vol. 55, pp. 98-108. http:// dx.doi.org/10.1016/j.cropro.2013.10.020.

FOLDI, I., 1983. Structure et fonctions des glandes tegumentaires des Cochénilles Pseudococcines et de leur sécrétion. Annales de la Société Entomologique de France, vol. 19, no. 5, pp. 155-166.

GLENN, D.M. and PUTERKA, G.J., 2005. Particle films: a new technology for agriculture. Horticultural Reviews, vol. 31, pp. 1-44.

GONÇALVES, S.G., SILVA, C.A.D., DUARTE, M.M.F. and VASCONCELOS, E.D., 2015. Oviposição do curuquerê e alimentação de suas lagartas neonatas em algodoeiros tratados com caulim. Pesquisa Agropecuária Brasileira, vol. 50, no. 7, pp. 526-533. http://dx.doi.org/10.1590/S0100-204X2015000700002.

HUANG, J., ZHANG, J., YU, Y.-M., LU, Y.-B. and LUAN, J.-B., 2012. Biological characteristic sand chemical control of the invasive mealybug, Phenacoccus solenopsis (Hemiptera: Pseudococcidae) on tomato in the laboratory. Journal of the Kansas Entomological Society, vol. 85, no. 3, pp. 179-185. http:// dx.doi.org/10.2317/JKES110711.1.

JOODAKI, R., ZANDI-SOHANI, N., ZARGHAMI, S. and YARAHMADI, F., 2018. Temperature-dependent functional response of Aenasius bambawalei (Hymenoptera: Encyrtidae) to different population densities of the cotton mealybug Phenacoccus solenopsis (Hemiptera: Pseudococcidae). European Journal of Entomology, vol. 115, pp. 326-331. http://dx.doi.org/10.14411/ eje.2018.032

JOSHI, M.D., BUTANI, P.G., PATEL, V.N. and JEYAKUMAR, P., 2010. Cotton mealybug, Phenacoccus solenopsis Tinsley: a review. Agricultural Reviews, vol. 31, no. 2, pp. 113-119.

KARMAKAR, P. and SHERA, P.S., 2017. Toxicity of insecticides to Aenasius arizonensis (Girault) (=Aenasius bambawalei Hayat), a solitary endoparasitoid of Phenacoccus solenopsis Tinsley on Bt cotton under semi-field conditions. Journal of Biological Control, vol. 31, no. 1, pp. 5-9. http://dx.doi.org/10.18311/jbc/2017/15594.

LIMA, M.S., MELO, J.W.S. and BARROS, R., 2018. Alternative food sources for the ladybird Brumoides foudrasii (Mulsant) (Coleoptera: coccinellidae). Brazilian Journal of Biology $=$ Revista Brasileira de Biologia, vol. 78, no. 2, pp. 211-216. http://dx.doi. org/10.1590/1519-6984.02816. PMid:28793028.

MAIA, A.H.N., LUIZ, A.J.B. and CAMPANHOLA, C., 2000. Statistical inference on associated fertility life table parameters using Jackknife technique: computational aspects. Journal of Economic Entomology, vol. 93, no. 2, pp. 511-518. http://dx.doi. org/10.1603/0022-0493-93.2.511. PMid:10826207.

MARKÓ, V., BLOMMERS, L.H.M., BOGYA, S. and HELSEN, H., 2008. Kaolin particle films suppress many apple pests, disrupt natural enemies and promote woolly apple aphid. Journal of Applied Entomology, vol. 132, no. 1, pp. 26-35. http://dx.doi. org/10.1111/j.1439-0418.2007.01233.x.

MATTSON JUNIOR, W.J. and HAACK, R.A, 1987. The role of drought in outbreak of plant-eating insects. Bioscience, vol. 37, no. 2, pp. 110-118. http://dx.doi.org/10.2307/1310365.

MILES, P.W., ASPINALL, D. and ROSENBERG, L., 1982. Performance of the cabbage aphid, Brevicoryne brassicae (L.), on water-stressed rape plants, in relation to the changes in their 
chemical composition. Australian Journal of Zoology, vol. 30, no. 2, pp. 337-345. http://dx.doi.org/10.1071/ZO9820337.

MILLER, D.R., 1991. The scales, scale insects or coccoids. In: F.W. STEHR, ed. Immature insects. Dubuque: Kendall/Hunt, pp. 90-107.

NAGRARE, V.S., KRANTHI, S., KUMAR, R., DHARAJOTHI, B., AMUTHA, M. and KRANTHI, K.R., 2016. Cotton. In: M. MANI and C. SHIVARAJU, eds. Mealybugs and their management in agricultural and horticultural crops. New Delhi: Springer, pp. 271-281. http://dx.doi.org/10.1007/978-81-322-2677-2_26.

NOUREEN, N., HUSSAIN, M., FATIMA, S. and GHAZANFAR, M., 2016. Cotton mealybug management: a review. Journal of Entomology and Zoology Studies, vol. 4, no. 4, pp. 657-663.

OLIVEIRA, M.D., BARBOSA, P.R.R., SILVA-TORRES, C.S.A., SILVA, R.R., BARROS, E.M. and TORRES, J.B., 2014. Reproductive performance of striped mealybug Ferrisia virgata Cockerell (Hemiptera: Pseudococcidae) on water-stressed cotton plants subjected to nitrogen fertilization. Arthropod-Plant Interactions, vol. 8, no. 5, pp. 461-468. http://dx.doi.org/10.1007/ s11829-014-9320-5.

POTTER, K.A., 2010. Life on a leaf: causes and consequences of oviposition-site choice in Manduca sexta. Tucson: University of Arizona, $129 \mathrm{f}$. PhD Dissertation.

PRASAD, Y.G., PRABHAKAR, M., SREEDEVI, G., RAMACHANDRA RAO, G. and VENKATESWARLU, B., 2012. Effect of temperature on development, survival and reproduction of the mealybug, Phenacoccus solenopsis Tinsley (Hemiptera: Pseudococcidae) on cotton. Crop Protection, vol. 39, pp. 81-88. http://dx.doi.org/10.1016/j.cropro.2012.03.027.

PRICE, P.W., 1997. Insect ecology. New York: J. Wiley \& Sons.

RAMASWAMY, S.B., 1988. Host finding by moths: sensory modalities and behaviors. Journal of Insect Physiology, vol. 34, no. 3, pp. 235-249. http://dx.doi.org/10.1016/0022-1910(88)90054-6.

SAS INSTITUTE, 2008. SAS/STAT ${ }^{\circledR}$ 9.2: user's guide. Cary: SAS Institute Inc.

SHOWLER, A.T. and ARMSTRONG, J.S., 2007. Kaolin particle film associated with increased cotton aphid infestations in cotton. Entomologia Experimentalis et Applicata, vol. 124, no. 1, pp. 55-60. http://dx.doi.org/10.1111/j.1570-7458.2007.00548.x.

SHOWLER, A.T., 2003. Effects of kaolin particle film on beet armyworm, Spodoptera exigua (Hübner) (Lepidoptera: Noctuidae), oviposition, larval feeding and development on cotton, Gossypium hirsutum L. Agriculture, Ecosystems \& Environment, vol. 95, no. 1, pp. 265-271. http://dx.doi.org/10.1016/S0167-8809(02)00101-9.

SILVA, A.L.A.L. and SILVA, C.A.D., 2015. Concentração eficiente e econômica de caulim para a proteção de algodoeiro contra o bicudo. Pesquisa Agropecuária Brasileira, vol. 52, no. 9, pp. 763-768. http://dx.doi.org/10.1590/S0100-204X2015000900004.
SILVA, C.A.D. and RAMALHO, F.S., 2013. Kaolin spraying protects cotton plants against damages by boll weevil Anthonomus grandis Boheman (Coleoptera: curculionidae). Journal of Pest Science, vol. 86, no. 3, pp. 563-569. http://dx.doi.org/10.1007/ s10340-013-0483-0.

SILVA, C.A.D., 2012. Occurrence of new species of mealybug on cotton fields in the states of Bahia and Paraíba, Brazil. Bragantia, vol. 71, no. 4, pp. 467-470. http://dx.doi.org/10.1590/S000687052013005000005

SILVEIRA, S.N., NAKANO, O., BARBIN, D. and NOVA, A.V., 1976. Manual de ecologia dos insetos. São Paulo: Agronomia Ceres.

SISTERSON, M.S., LIU, Y.B., KERNS, D.L. and TABASHNIK, B.E., 2003. Effects of kaolin particle film on oviposition, larval mining, and infestation of cotton by pink bollworm (Lepidoptera: gelechiidae). Journal of Economic Entomology, vol. 96, no. 3, pp. 805-810. http://dx.doi.org/10.1093/jee/96.3.805. PMid:12852620.

TOK, B., KAYDAN, M.B., MUSTU, M. and ULUSOY, M.R., 2016. Development and life table parameters of Phenacoccus madeirensis Green (Hemiptera: Pseudococcidae) on four ornamental plants. Neotropical Entomology, vol. 45, no. 4, pp. 389-396. http://dx.doi.org/10.1007/s13744-016-0387-9. PMid:26951150.

TORRES, J.B. and RUBERSON, J.R., 2006. Spatial and temporal dynamics of oviposition behavior of bollworm and three of its predators in $\mathrm{Bt}$ and non-Bt cotton fields. Entomologia Experimentalis et Applicata, vol. 120, no. 1, pp. 11-22. http:// dx.doi.org/10.1111/j.1570-7458.2006.00422.x.

VENNILA, S., DESHMUKH, A.J., PINJARKAR, D., AGARWAL, M., RAMAMURTHY, V.V., JOSHI, S., KRANTHI, K.R. and BAMBAWALE, O.M., 2010. Biology of the mealybug, Phenacoccus solenopsis on cotton in the laboratory. Journal of Insect Science, vol. 10, no. 115, pp. 1-9. http://dx.doi.org/10.1673/031.010.11501. PMid:20874596.

WHITE, T.C.R., 1969. An index to measure weather-induced stress of trees associated with outbreaks of psyllids in Australia. Ecology, vol. 50, no. 5, pp. 905-909. http://dx.doi.org/10.2307/1933707.

WILLIAMS, D.J., 1991. Superfamily Coccoidea. In: I.D. NAUMANN, ed. The insects of Australia. New York: Cornell University, pp. 457-464.

ZAZYCKI, L.C.F., SEMEDO, R.E.S., SILVA, A., BISOGNIN, A.Z., BERNARDI, O., GARCIA, M.S. and NAVA, D.E., 2015. Biology and fertility life table of Eriopis connexa, Harmonia axyridis and Olla v-nigrum (Coleoptera: coccinellidae). Brazilian Journal of Biology = Revista Brasileira de Biologia, vol. 75, no. 4, pp. 969-973. http://dx.doi.org/10.1590/1519-6984.03814. PMid:26675915.

ZHANG, Y., XIE, Y., XUE, J., FU, X. and LIU, W., 2012. The structure of integument and wax glands of Phenacoccus fraxinus (Hemiptera: Coccoidea: Pseudococcidae). Zoological Research, vol. 33, no. 1-2, pp. 13-17. PMid:22653865. 